\title{
NURSERY PROTECTION TO ENHANCE AGRICULTURAL YIELD AND PROMOTE SUSTAINABILITY IN CHILLI FARMING
}

\author{
EVY LATIFAH ${ }^{1 *}$, ELI KORLINA ${ }^{2}$, APRI KUNTARININGSIH ${ }^{3}$ AND ENNY SUSWATI ${ }^{4}$ \\ ${ }^{1}$ Balai Pengkajian Teknologi Pertanian - Jawa Timur, Badan Penelitian dan Pengembangan Pertanian, Kementrian \\ Pertanian Republik Indonesia. ${ }^{2}$ Balai Penelitian Sayuran - Lembang, Badan Penelitian dan Pengembangan Pertanian, \\ Kementrian Pertanian Republik Indonesia. ${ }^{3}$ Fakultas Ilmu Sosial dan Politik, Universitas Pancasakti, Tegal - Indonesia. \\ ${ }^{4}$ Fakultas Kedokteran, Universitas Jember, Jember-Indonesia.
}

*Corresponding author: epilatip08@gmail.com

Submitted final draft: 27 July $2020 \quad$ Accepted: 8 October 2020

http://doi.org/10.46754/jssm.2021.07.005

\begin{abstract}
In tropical areas, farmers face many challenges in cultivating chilli, especially from pest attacks and diseases. This study aims to assess the impact of nursery protection and plant variety on chilli yield. The experiment was conducted in Kediri, East Java, in the wet season, using two factors in a randomized complete block design, i.e. factor one (use of protective nurseries and without protection) and factor two (varieties of AVPP1102B

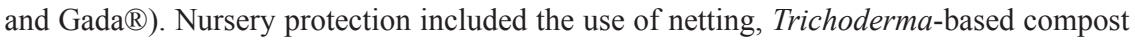
and plant-growth-promoting-rhizobacteria (PGPR) treatment. The results showed that chilli plants from a protected nursery and of the AVPP1102B variety had better yield in terms of quantity and weight of fruits. The Gada ${ }^{\circledR}$ variety was prone to wilt diseases. The level of diseases caused by wilt, viruses, anthracnose and blight on chilli plants without nursery protection was higher than those with protection. The Gada ${ }^{\circledR}$ variety was more susceptible to wilting, viruses, anthracnose and blight than AVPP1102B. There is a relationship between nursery protection and plant variety in terms of observed pests and diseases. Nursery protection may enhance the growth and yield of chilli plants, and the sustainability of chilli farming may be improved by replacing the use of harmful chemicals with natural protective agents like Trichoderma compost and PGPR treatment.
\end{abstract}

Keywords: Chilli, protected nursery, sustainability, agrochemicals, farming.

\section{Introduction}

Chilli (Capsicum annuum L.) is one of the horticultural crops cultivated globally. Global production of chilli has grown with an average of $3.9 \%$ per year during the last decade, led by a steady increase of demand in Asia. Based on data from the Food Agriculture Organisation (FAO), Indonesia is the fourth largest chilli producer, with an annual yield of 1.8 million tonnes valued at US\$812,000. In addition to meeting the culinary needs of many households, chilli is also widely used as a raw material in the food and pharmaceutical industries. Chillies may be marketed and sold fresh or dried, or converted into powder and paste to serve as a base ingredient in all kinds of foodstuff (Maramis, 2018).

Chilli is also an important crop that provides significant contribution to the local and national economy through its multiplier effects. Shifting from subsistence grain farming to chilli-based agribusiness may make rural economies more vibrant by increasing employment opportunities and material-intensive farming. Intensification of chilli farming will boost the local economy, particularly through agricultural inputs and products. Chilli is a high-value crop and needs a lot of input to cultivate, particularly labour, compared with grain and other staples (Mariyono, 2017). The multiplier effects of chilli cultivation include employment creation, agribusiness development and improvements in local transportation, all of which will accrue to the rural community. At the national level, chilli cultivation provides a good income, steady employment and nutritional benefits to millions of smallholder farmers, labourers and consumers.

The Gada ${ }^{\circledR}$ variety is widely planted in East Java, particularly in Kediri and Blitar districts. 
This variety is chosen because of its erect growth, early maturity and bright red fruits. Many consumers prefer these characteristics, but its cultivation is often hampered by diseases, such as anthracnose and fusarium wilt. The average yield of the Gada ${ }^{\circledR}$ variety have remained steady between 6.88 and 7.78 tonnes per hectare, according to the Indonesian Agriculture Ministry (2020). It is the dynamics of chilli-cultivating areas that affect production levels. Compared to regional and international standards, the average yield of chillies in Indonesia is considered very low (Ali, 2016) and far below the potential of 15 to 20 tonnes per hectare (Indonesian Commercial Newsletter, 2013). The low yield is due to many factors, such as pest and disease outbreaks, besides extreme weather. These indicate that better management practices are needed to overcome the challenges in increasing national production of chilli by enhancing crop productivity without sacrificing the production of other crops (Johnson et al., 2008).

Various types of pests and diseases often attack chilli plants in both vegetative and generative stages. The regular pests include armyworms (Spodoptera litura Fab.), aphids (Myzus persicae Sulzer), thrips and whiteflies (Bemisia tabaci Gen.). Setiawati et al. (2005) reported that yield losses caused by pests may range from $20 \%$ to $100 \%$ of a farm. Whiteflies may damage crops by puncturing and damaging the internal structures of the plants as they feed on sap. They are also known to be vectors for many types of microbes and funguses (Byrne \& Bellows, 1991; Tiwari et al., 2013). These insects may introduce the tomato yellow leaf curl virus and Gemini viruses, among others, that cause critical diseases in plants like wilting, blights and anthracnose.

Currently, farmers mainly rely on pesticides and fungicides because of their practicality (Mariyono et al., 2018a) and effectiveness (Mariyono, 2009) in keeping crop pests and diseases at bay. However, the use of chemicals may lead to health and environmental problems (Mariyono et al., 2018b). Overuse of pesticides has been observed to cause collateral damage, in which the natural enemies of targeted pests are also destroyed. This may result in pest resurgence as there are no more natural predators to keep the pest population in check. Besides, the spraying of pesticides and fungicides also raises concern of residues on crops that may be harmful to human health when consumed (Latha \& Hunumanthraya, 2018). Chemical residues found in chillies will hinder its export, especially to rich and developed countries, as authorities and consumers are more aware of their danger and risks. Overuse of chemical components will also result in the development of resistance in pathogenic isolates, which will further augment the difficulty in managing diseases (Amrita et al., 2016)

In the concept of integrated pest and disease management (IPDM), pesticides are recommended only if other control measures are not effective, and they should be used as a last resort based on field observations (Mariyono, 2008). With IPDM, farming practices have changed from chemical-augmenting to chemical-saving technology (Mariyono, 2015), resulting in a reduced use of agrochemicals (Mariyono, 2018a; Mariyono et al., 2013; Luther et al., 2018).

The reduction of pesticide and fungicide use may likely be achieved by incorporating IPDM components, such as technical culture, growing pest- and disease-resistant crop varieties, and using biological agents. Some biological agents for disease control have been widely produced and used. Trichoderma spp. (Moosa et al., 2017) and Pseudomonas fluorescence Flug. (Tamang et al., 2017) have been used as bio-control components of IPDM in many crop protection strategies. The combination of antagonist microorganisms to control pests and diseases has indicated a positive effect in crop growth (Mathivanan et al., 2005). Korlina et al. (2013) reported that the application of Trichoderma spp. and P. fluorescence may prevent wilt diseases in chilli crops. Along with Trichoderma spp. (Moosa et al., 2017), plant-growth-promoting-Rhizobacteria (PGPR) 
is also a potential component used in IPDM (Gupta et al., 2018; Paramanandham et al., 2017). These soil bacteria colonises the roots of crops following inoculation onto seeds, which will then enhance plant growth.

Technical culture may be carried out by using 60-mesh netting in the nursery to protect seedlings from aphids and whitefly infestation, as well as other vectors of bacterial and viral diseases (Gunaeni et al., 2009). This is because the seedlings in nursery stage are still very susceptible, particularly to viruses transmitted by whiteflies (Yoshihiro et al., 2016). If the seedlings become infected in the early stage, the crops will not develop normally when they are transplanted to the field.

When agrochemicals are, to a larger extent, substituted with components of IPDM, farming will then become more sustainable. This will result in higher social, economic and environmental benefits of chilli farming that adopts an environmentally friendly technology. IPDM components have been proven to be effective alternatives to the application of chemicals and as growth promoters in crop production. They are the promising methods to attaining environmental friendly outcomes in farming (Morales-Corts et al., 2018). This study aims to analyze the effects of using protected nursery with IPDM components on two varieties of chilli seedlings to gauge the protection it provides against pests and diseases, and its agronomic development of the crop in the field.

\section{Materials and Methods}

The present study was conducted at a chilli farm in Pagu Kediri, East Java, Indonesia, during the wet season in 2014. Two chilli seeds were planted in a $3 \mathrm{~cm}$ polybags filled with planting media. The planting media comprised a Trichodermabased compost, soil and fertilizer in a 1:6:6 ratio. Before the seeds were put into the planting medium, they were first subjected to PGPR treatment. Besides rhizobacteria, P. fluorescence was also introduced to the seeds at this stage. All microorganisms were sourced from the
Laboratory of Plant Protection Agency in East Java, Indonesia. The PGPR The application was made by mixing the agent on the planting media. The nursery was then covered with 60 mesh gauze shells (fluffy). The application of Trichoderma and PGPR were meant to control soil-borne diseases, while the nylon netting would protect against insects and other pests. Two-week old chilli seedlings that had sprouted with four to five leaves were transplanted to the field. Applications of Trichoderma and PGPR were conducted during the stages in nursery. The composition of Trichoderma and soil was $1: 1$; and the concentration of PGPR was $5 \mathrm{ml} / \mathrm{L}$.

The study employed a two-factorial analysis. Factor one was the protected nursery (S1) stage, where seedlings were protected with netting and biological agents as described. As a comparison, an unprotected nursery (S2) without netting, Trichoderma-based compost, and $P$. fluorescence and PGPR treatment, which was commonly practiced among local farmers - was set up as negative control. Factor two was the variety of chilli plants. This study used a new and improved line known as AVPP1102B (V1), which was introduced by the World Vegetable Center (AVRDC) in Taiwan. As comparison, the Gada ${ }^{\circledR}$ variety (V2) had been commonly cultivated by farmers. Each treatment was repeated six times. The variables measured in this study included plant growth, infestation of pests and diseases, and harvest in terms of weight and number of fruits.

1. The incidence of the disease is calculated by the formula in Equation 1 (Sinaga, 2003):

$$
\mathrm{KP}=(\mathrm{n} / \mathrm{N}) \times 100 \%
$$

where $\mathrm{n}=$ number of plants attacked and $\mathrm{N}=$ number of plants determined

2. The severity of a disease attack could be reflected by the intensity of the disease, calculated using Equation 2:

$$
\mathrm{IP}=[\Sigma(\mathrm{n} \times \mathrm{v})] /(\mathrm{N} \times \mathrm{Z}) \times 100 \%
$$

where IP $=$ disease intensity, $\mathrm{n}=$ number of plants from each attack category, $\mathrm{v}=$ scale value 
of each attack category, $\mathrm{N}=$ number of sample plants, and $\mathrm{Z}=$ score from the highest attack category.

The number and weight of fruits were counted at harvesting time in two-week intervals. At each harvest, the number of healthy fruits and those affected by anthracnose and Phytophthora infestation were counted. The data were subjected to two-factor experiments in a randomized complete block design using the SAS 6.12 software. Means were separated using Duncan's multiple range test (Gomez \& Gomez, 1984). Analysis of variance was carried out and if there were significant differences between the groups, the completion of the Duncan Multiple Range Test (DMRT) would be calculated at $\alpha=$ 0.05 .

\section{Results and Discussion}

Based on the observation of plant growth (height and canopy), it appeared that the use of protective nurseries and chilli variety could produce significant differences in yield compared with the negative controls. Plants grown under mesh netting and with Trichoderma and PGPR treatment were healthier with more height and canopy. The Gada ${ }^{\circledR}$ variety could grow higher than AVPP1102B, most likely because it had long been adapted in chilli production centres throughout Indonesia, besides being an indeterminate variety, whereas the AVPP1102B variety was a newly introduced and determinate variety. The interaction between growth in a protective nursery and varieties was significant. Both varieties showed better height and canopy when sprouted in a nursery as shown in Table 1.

Trichoderma and PGPR were reported as microorganisms that could promote crop growth (Murali et al., 2012). Ashraf et al. (2013) stated that the mechanism of PGPR might probably be the production of phytohormones, biological nitrogen fixation and increase of nutrient availability by the bacteria at the roots, which were easily absorbed by the crops. Crops treated with PGPR and Trichoderma reportedly had

Table 1. Mean height and canopy $(\mathrm{cm})$ of AVPP1102B and Gada ${ }^{\circledR}$ chilli plants when grown with and without rotective nursery

\begin{tabular}{|c|c|c|c|c|c|c|c|c|c|c|c|c|}
\hline \multirow{3}{*}{$\begin{array}{l}\text { Treatment } \\
\text { Nursery (S) }\end{array}$} & \multicolumn{6}{|c|}{ Plant height } & \multicolumn{6}{|c|}{ Diameter of plant canopy } \\
\hline & \multicolumn{3}{|c|}{14 DAP } & \multicolumn{3}{|c|}{28 DAP } & \multicolumn{2}{|c|}{14 DAP } & & \multicolumn{3}{|c|}{$28 \mathrm{DAP}$} \\
\hline & Mean & Sd. & & Mean. & Sd. & & Mean. & Sd. & & Mean & Sd. & \\
\hline S1: Protected & 24.25 & 1.11 & $\mathrm{~b}$ & 40.48 & 2.03 & $\mathrm{~b}$ & 12.71 & 0.51 & $\mathrm{a}$ & 27.64 & 0.18 & $b$ \\
\hline S2: no treatment & 17.63 & 0.80 & $\mathrm{a}$ & 36.2 & 1.82 & $\mathrm{a}$ & 11.73 & 0.47 & $\mathrm{a}$ & 24.17 & 0.16 & $\mathrm{a}$ \\
\hline \multicolumn{13}{|l|}{ Variety (V) } \\
\hline V1: AVPP1102B & 18.73 & 0.85 & $\mathrm{a}$ & 31.16 & 1.56 & $\mathrm{a}$ & 10.72 & 0.43 & $\mathrm{a}$ & 20.19 & 0.13 & $\mathrm{a}$ \\
\hline V2: Gada ${ }^{\circledR}$ & 23.15 & 1.06 & $\mathrm{~b}$ & 45.51 & 2.29 & $\mathrm{~b}$ & 13.72 & 0.55 & $\mathrm{~b}$ & 31.61 & 0.21 & $\mathrm{~b}$ \\
\hline \multicolumn{13}{|l|}{ Nursery $x$ Variety } \\
\hline S1V1 & 20.07 & 0.92 & $\mathrm{~b}$ & 30.55 & 1.53 & $\mathrm{a}$ & 10.54 & 0.42 & $\mathrm{a}$ & 19.9 & 0.13 & $\mathrm{a}$ \\
\hline S1V2 & 28.44 & 1.30 & $\mathrm{~b}$ & 50.4 & 2.53 & $\mathrm{~b}$ & 14.88 & 0.59 & $\mathrm{~b}$ & 35.38 & 0.23 & b \\
\hline S2V1 & 17.4 & 0.79 & $\mathrm{a}$ & 31.78 & 1.60 & $\mathrm{a}$ & 10.89 & 0.43 & $\mathrm{a}$ & 20.49 & 0.13 & $\mathrm{a}$ \\
\hline S2V2 & 17.86 & 0.81 & $\mathrm{a}$ & 40.63 & 2.04 & $\mathrm{~b}$ & 12.56 & 0.50 & $a b$ & 27.85 & 0.18 & $\mathrm{~b}$ \\
\hline \# replication & 6 & & & 6 & & & 6 & & & 6 & & \\
\hline$p>F$ & 0.021 & & & 0.032 & & & 0.022 & & & 0.037 & & \\
\hline
\end{tabular}

Note: DAP stands for days after planting; number followed by the same letter are statistically insignificant according to Duncan's multiple range test $(P=0.05)$. 
improved germination rates of up to $91 \%$. The PGPR treatment also contained $P$, fluorescence, which could dissolve phosphate and nitrogen, which were important nutrients that plants needed to absorb from the planting media (Thakuria et al., 2004).

Observations of disease in chilli plants were conducted during the vegetative and generative stages. They included wilt, blights, virus infection and anthracnose. Based on statistical analysis, there was no significant difference between the use of a protected nursery and plant variety with their negative controls in relation to blight caused by Phytophthora capsicii, but it appeared that a single factor was crucial to the existence of the disease. Wilt disease mostly affected Gada ${ }^{\circledR}$ plants, which accounted for $7.11 \%$ of total incidents. This disease incidence increased to $20.63 \%$ at 28 days after planting (DAP) and $70 \%$ at 56 DAP (see Table 2).

The resistance of chilli plants against blights was closely linked to variety. For instance, Gada ${ }^{\circledR}$ was more susceptible to the disease than AVPP1102B. Hardaningsih (2011) found that blights could be caused by many organisms, such as Phytophthora sp, Pythium sp., Fusarium $\mathrm{sp}$, Rhizoctonia capsicii and Sclerotium rolfsii.

Another important disease is the yellow leaf symptom caused by viruses. Statistical analysis showed that there was no significant difference between nursery protection and variety with their negative controls in viral infection. However, crops from unprotected nursery and the Gada ${ }^{\circledR}$ variety showed higher susceptibility to infection at 49 DAP (see Figure 1). One possible explanation was that the viruses had infected the plants in the nursery, but the symptoms were latent and became observable only after 28 DAP. It could also be the case of seed treatment with PGPR and Trichoderma had induced plantresistance to viruses. This was in line with the results of Taufik et al. (2005), which found that pepper plants treated with PGPR could suppress the manifestations of a virus infection, and the crops could still produce normally.

The dominant pests found in the chilli plants of this study were aphids. Statistical analysis showed that there was no significant difference between the use of a protected nursery and chilli varieties with aphid infestation. Aphids were found in chilli plants at 14 DAP. Despite not being statistically significant, the highest population of aphids (7.7 aphids/plant) were found in crops from the unprotected nursery. At 28 DAP, the population of aphids had decreased to 1-2 aphids/plant (see Figure 2). The different varieties had an impact on aphid infestation, where the chilli line of AVPP1102B had lower aphid population than $\mathrm{Gada} \AA$.

Table 2. The percentage of blight-infected chilli plants (Phytophthora capsicii)

\begin{tabular}{|c|c|c|c|c|c|c|c|c|c|}
\hline \multirow{3}{*}{$\begin{array}{l}\text { Treatment } \\
\text { Nursery (S) }\end{array}$} & \multicolumn{9}{|c|}{ Incidence of wilt diseases (\%) } \\
\hline & \multicolumn{3}{|c|}{28 DAP } & \multicolumn{3}{|c|}{ 35DAP } & \multicolumn{3}{|c|}{56 DAP } \\
\hline & Mean & Sd. & & Mean & Sd. & & Mean & Sd. & \\
\hline S1. Protected & 3.26 & 0.11 & $\mathrm{a}$ & 15.63 & 0.43 & $\mathrm{a}$ & 46.88 & 2.97 & $\mathrm{~b}$ \\
\hline S2. not treatment & 4.47 & 0.15 & $\mathrm{a}$ & 11.25 & 0.31 & $\mathrm{a}$ & 34.38 & 2.18 & a \\
\hline Variety (V) & & & & & & & & & \\
\hline V1. AVPP1102B & 0.63 & 0.02 & $\mathrm{a}$ & 6.25 & 0.17 & $\mathrm{a}$ & 11.25 & 0.71 & a \\
\hline V2. Gada ${ }^{\circledR}$ & 7.11 & 0.24 & $\mathrm{~b}$ & 20.63 & 0.57 & $\mathrm{~b}$ & 70 & 4.44 & $\mathrm{~b}$ \\
\hline \# replication & 6 & & & 6 & & & 6 & & \\
\hline $\mathrm{p}>\mathrm{F}$ & 0.014 & & & 0.018 & & & 0.026 & & \\
\hline
\end{tabular}

Note: DAP stands for days after planting; number followed by the same letter are statistically not significant according to Duncan's multiple range test $(P=0.05)$. 


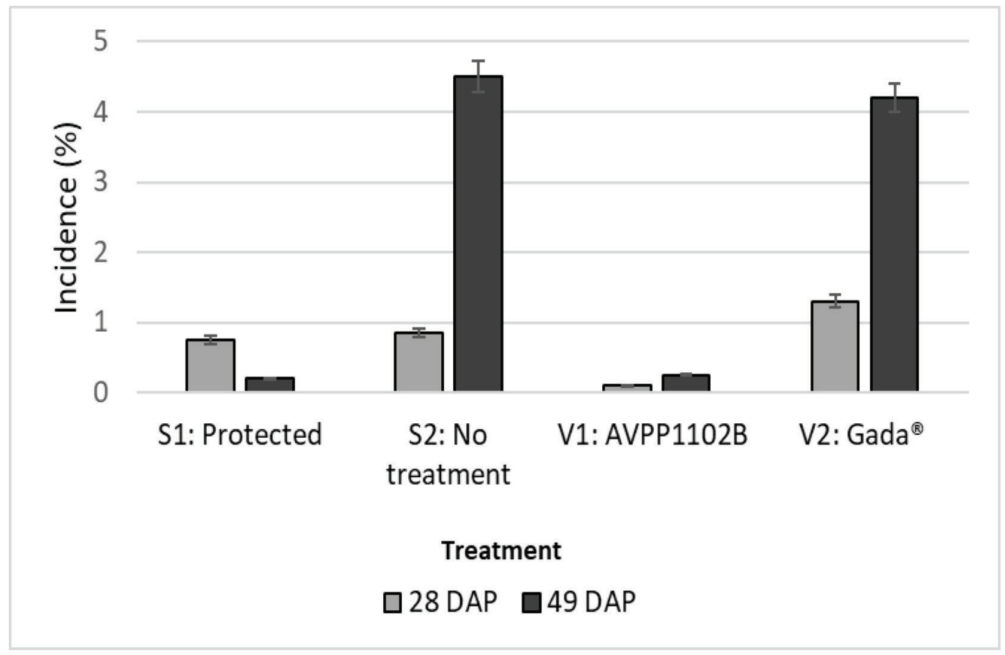

Figure 1: Incidence of virus infection in chilli plants grown with or without a protected nursery and their variety

Note: S1 represents protected nursery, S2 represents unprotected nursery commonly practiced by local farmers, V1 is AVPP 1102B variety and V2 is the Gada ${ }^{\circledR}$ variety. DAP stands for days after planting.

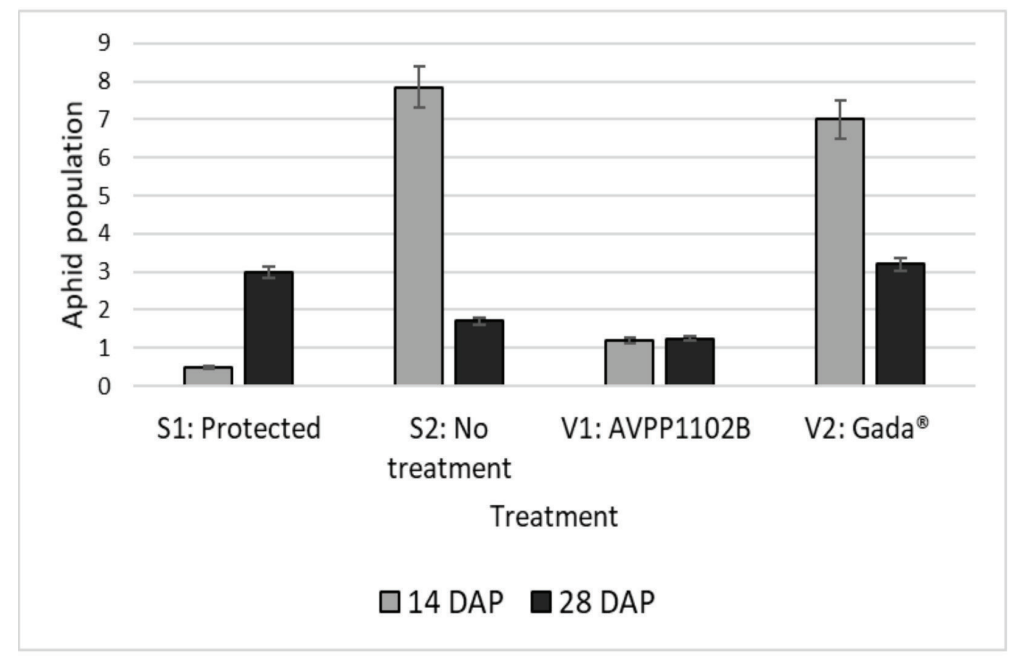

Figure 2: The population of aphids found in chilli plants grown with or without a protected nursery and their variety

Note: S1 represents protected nursery, S2 represents unprotected nursery commonly practiced by local farmers, V1 is AVPP 1102B variety and V2 is the Gada ${ }^{\circledR}$ variety. DAP stands for days after planting.

Anthracnose (fungal infection that causes dark lesions on plants) and Phytophthora infection (water moulds that causes plants to rot) mostly occurred in the generative stage. Anthracnose incidence was higher in chilli grown from the unprotected nursery group and Gada ${ }^{\circledR}$ variety (Figure 3 ). This indicated that the use of a protected nursery was able to reduce the disease incidence, besides the AVPP1102B variety showing more resistance than Gada $\AA$.

Anthracnose was caused by the Colletotrichum fungus that mainly infected chilli crops, which could lead to severe post-harvest loss (Oanh et al., 2004). Two 
species of Colletotrichum - C. capsici and C. gloeosporioidesare - had been identified as pathogens responsible for anthracnose in chilli crops, and they were usually controlled at seeding stage (Jayawardanah et al., 2015). Kazuyoshi et al. (2017) stated that planting seedlings in a protective nursery, which were geographically isolated from fields where the anthracnose fungus was often found, was a very important step to prevent disease exposure in early growth. According to Alam et al. (2014), fungal pathogens could prevent seeds from germinating and cause morphological disorders to seedlings, subsequently reducing their survivability and causing them to die. Therefore, it was imperative to prevent anthracnose in chilli plants at the earliest stage of cultivation through the use of a protected nursery.

Initially, there was no significant difference between the use of protected nursery and different variety against anthracnose with their negative controls. In the first harvest, the average incidence of anthracnose was about six to eight per cent, which was almost similar. It increased in the following harvests, and became significant in the third and fourth harvest.
For Phytophthora infection, there was also no significant difference between the use of a protected nursery and different variety with their negative controls. It seemed that almost all treatments showed symptoms of Phytophthora infection. The most severe attack in chilli plants could be observed in those coming from the unprotected nursery and Gada ${ }^{\circledR}$ variety, even though initially, both chilli plants from an unprotected nursery and the Gada ${ }^{\circledR}$ variety showed a lower level of disease incidence (see Figure 4).

The total production of chilli from four harvests is shown in Figure 5. There was no significant difference between protected nursery and chilli variety. However, each factor affected the production of chilli in terms of the number and weight of fruits. The use of a protected nursery led to higher yield of chilli compared to unprotected plants. The same case occurred with different varieties, where the production of AVPP1102B was higher than Gada ${ }^{\circledR}$ in terms of number and weight of fruits. The better chilli harvest with the use of protected nursery and AVPP1102B variety was the result of lower incidents of pest infestation and disease,

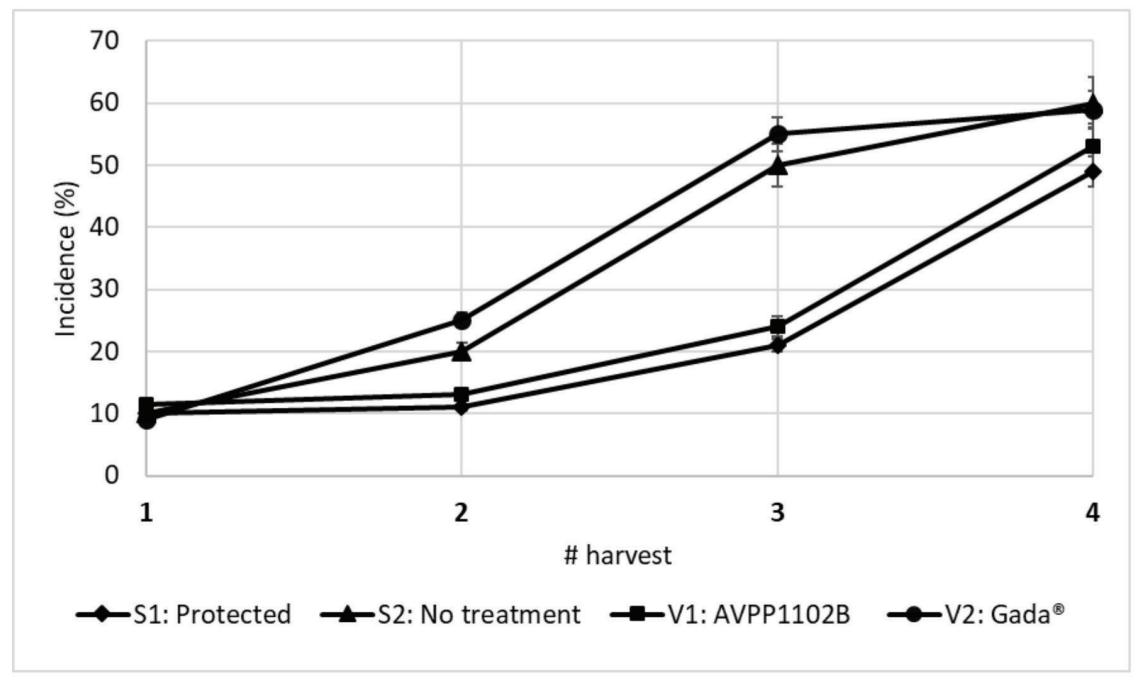

Figure 3: The dynamics of anthracnose on chilli chilli plants grown with or without a protected nursery and their variety

Note: S1 represents protected nursery, S2 represents unprotected nursery commonly practiced by local farmers, $\mathrm{V} 1$ is AVPP $1102 \mathrm{~B}$ variety and V2 is the Gada ${ }^{\circledR}$ variety. 


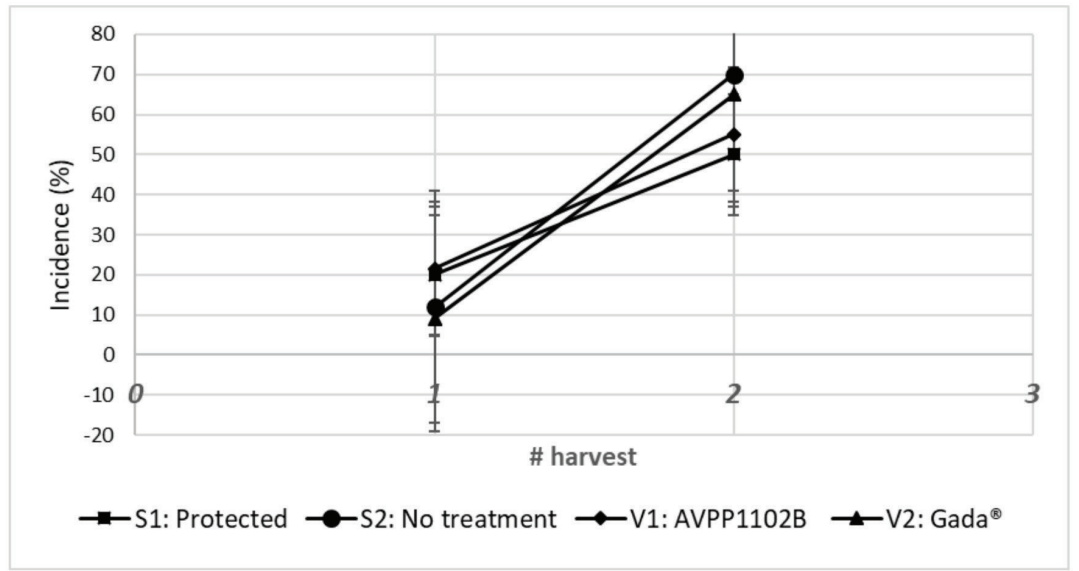

Figure 4: The disease incidence of Phytophthora capsicii infestation on chilli plants grown with or without a protected nursery and their variety

Note: S1 represents protected nursery, S2 represents unprotected nursery commonly practiced by local farmers, $\mathrm{V} 1$ is AVPP $1102 \mathrm{~B}$ variety and V2 is the Gada ${ }^{\circledR}$ variety.

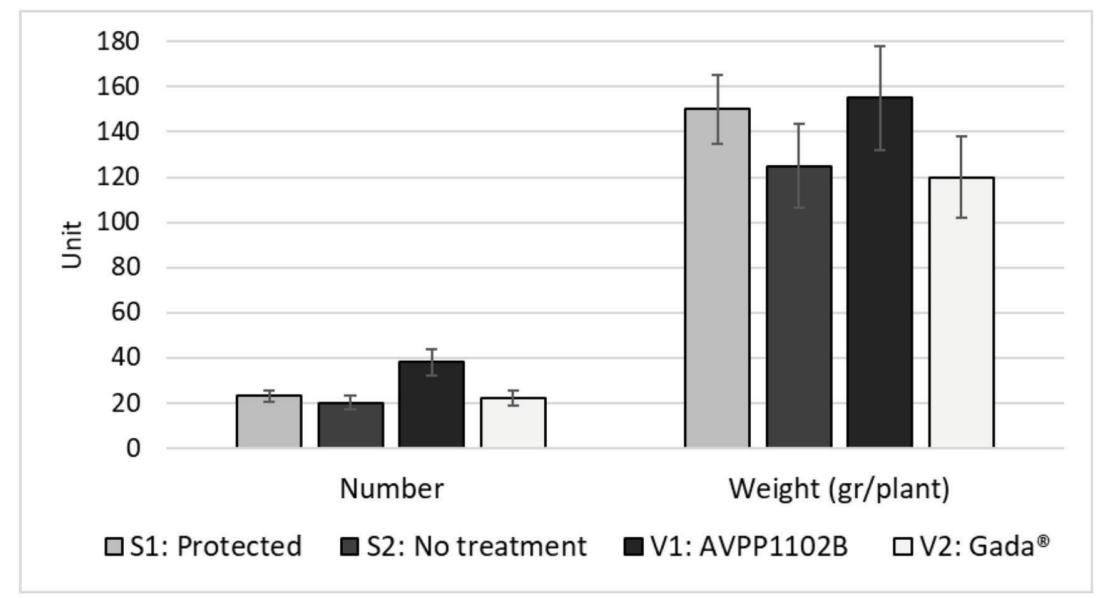

Figure 5: The number of fruits and weight of chilli fruit produced by chilli plants grown with or without a protected nursery and their variety.

Note: S1 represents protected nursery, S2 represents unprotected nursery commonly practiced by local farmers, V1 is AVPP $1102 \mathrm{~B}$ variety and V2 is the Gada ${ }^{\circledR}$ variety.

both in the vegetative and generative stages. This study found that the use of beneficial microorganisms, combined with fertilizer and consistent irrigation, could improve plant height and dry weight (Russo, 2006). In particular, when seedlings were inoculated with beneficial microorganisms, the average pod fresh weight of the plants would be greater than that of conventionally grown seedlings (Russo \& Perkins-Veazie, 2010).
It had been proven that the improved chilli variety could provide better harvest than those locally grown by farmers. Mariyono (2018b) provided a comprehensive analysis on the impact of using better seed technology on the economic aspects of chilli production. Farmers were provided with many chilli varieties that were suitable to grow in their own land. It should be noted that improvement in agronomic technology for chilli did not merely improve 
harvest by lowering the incidence of pests and diseases. An appropriate recommendation to reduce the risk of pest attacks and diseases in chilli cultivation was to avoid continually planting on the same plot of land for a long time. Crop rotation was needed to avoid accumulated infestations of pests and diseases.

Environmental conditions could also modify crop yield. Cumulative yield of vegetables cultivated in two-year rotations were higher than those planted in the middle of a fouryear rotation (Russo, 2003). It was also strongly recommended to use organic fertiliser on chilli plants so that beneficial microbes could help promote a normal growth. These microbes could demonstrate antagonism towards the growth of other pathogenic microorganisms (Tian \& Zheng, 2013). Green manure, particularly for liquid compost, had been identified to be able to suppress various crop diseases. The compounds consisted of beneficial microbes for plant disease management (Orlikowski \& Wolski, 2000; Quarles, 2001) by impeding the reproductive structure of germination, increasing the number of non-threatening microorganisms, and inducing systemic and locally acquired resistance in crops (Deepthi \& Reddy, 2013).

Liquid compost could be used as a potential substitute to fungicides, and as growth promoters in crop production, to attain environmental sustainability for farming practices (MoralesCorts et al., 2018). The application of liquid compost combined with inorganic fertilizer could significantly enhance vegetative growth, yield and antioxidant contents (Siddiqui et al., 2011). Economically, the application of manure in vegetables produced higher returns than conventional fertilizer. An annual application of manure appeared to be necessary for most of the vegetable crops (Russo \& Taylor, 2010). Using a protected nursery might potentially reduce the use of pesticides up to a rational level, yet still increase the production of chilli, and simultaneously improve the sustainability of chilli farming (Pretty et al., 2011).

Nevertheless, the use of pesticides should not be totally discounted because it might still be required in a specific context. However, reducing its usage was the most feasible and acceptable way to achieve sustainable farming. In this study, the use of nursery protection had good potential to effectively reduce the dependence on pesticides in chilli cultivation.

The economic aspect also played an important role in convincing farmers to adopt the use of protected nurseries (Mariyono, 2018b; Russo, 2003). One important thing to take note was that farmers should be provided flexible access to credit (Mariyono, 2019a) to encourage them to adopt improved agronomic technologies (Mariyono, 2019b). Superior agronomic technologies with poor economic aspects would result only in the farmers' failure to adopt such technologies, which would not bring any economic benefits. Alternatively, farmers could adopt off-season technology (Korlina et al., 2017) and utilise information systems (Negoro and Mariyono, 2014; Mariyono, 2019c) to increase profitability from the better price of their produce during the off-season.

\section{Conclusion}

In terms of agricultural performance, this study had proven that nursery management played an essential role in the production of chilli. Using a combination of Trichoderma-based compost, PGPR treatment and mesh netting in a nursery to protect the chilli seedlings could increase their harvest. The production chilli could be improved because of the low incidence of disease and pest infestation. Using a better variety of chilli could also improve production. In this case, the AVPP1102B variety developed by The World Vegetable Center in Taiwan might be suitable to grow during the wet season.

Practically, organic-based materials had been used rationally to substitute the use of pesticides and fungicides. This substitution could potentially lead to enhanced sustainability in chilli cultivation. These technological changes were able to increase farm harvests, and when farmers become familiar with these technologies, they would not face significant trouble in applying them. 
This study had several limitations, including sample size, planting location and season. Future studies should involve multiple planting locations and various seasons. There were different pests and diseases affecting chilli producing regions in Indonesia. The findings of this study might be suitable for application only in Kediri district in East Java or other areas with similar agro-ecology characteristics. Another recommendation was to conduct an economic analysis to determine if it was practical for farmers to adapt to the use of protected nurseries. The goal of improvement in agricultural technology was not all about production per se, but also to provide better income for farmers.

\section{Acknowledgements}

This study was part of the "Vegetables for Indonesia" project funded by the United States Agency for International Development(USAID)Indonesia, in collaboration with AVRDC-The World Vegetable Center, Indonesian Vegetables Research Institute, Assessment Institute for Agricultural Technology East Java and Bali, Agricultural Extension Service of East Java and Bali, Udayana University and FIELD Foundation Indonesia. Special thank to Dr. Greg Luther, Dr. Kuntoro B. Andry and Ms. Hanik Anggraeni Dewi for their valuable assistance in the field trials.

\section{References}

Alam, M. Z., Hamim, I., Ali, M. A. \&. Ashrafuzzaman, M. (2014). Effect of seed treatment on seedling health of chilli. Journal of Environmental Science and Natural Resources, 7(1): 177-181.

Ali, M. (2016). A synthesis. In: Ali, M (Ed.), Chilli (Capsicum spp.) Food Chain Analysis: Setting Research Priorities in Asia, Taiwan: AVRDC - The World Vegetable Center, pp. 1-20.

Amrita S., Raghuwanshi, R., Vijai K. G. \& Singh, H. B. (2016). Chilli anthracnose: the epidemiology and management. Frontiers in Microbiol, 7(1): 1-18.
Ashraf, M. A., Asif, M., Zaheer, A., Malik, A., Ali, Q. \& Rasool, M. (2013). Plant growth promoting rhizobacteria and sustainable agriculture: a review Plant growth promoting rhizobacteria and sustainable agriculture: A review. African Journal of Microbiology Resource, 7(9): 704-709. https://doi.org/10.5897/AJMR12.936

Byrne, D. N. \& Bellows, T. S. (1991). Whitefly biology. Annual Review of Entomology, 36(1): 431-457. https://doi.org/10.1146/ annurev.en.36.010191.002243

Deepthi, K. P. \& Reddy, P. N. (2013). Compost teas: a potential source of antagonistic microflora against plant diseases. Journal of Cell and Life Sciences, 1(1): 6-19.

FAOSTAT. (2013). FAO-STAT online. Rome: United Nations Food and Agriculture Organization, http://faostat.fao.org/default/ aspx?lang-en

Gomez, K. A. \& Gomez, A. A. (1984). Statistical Procedures for Agricultural Research (2nd Editio). Toronto: John Wiley \& Sons, Inc.

Gunaeni, N., Setiawati, W., Murtiningsih, R. \& Rubiati, T. (2009). Penyakit Virus Kuning dan Vektornya serta Cara Pengendaliannya pada Tanaman Sayuran. Bandung: Balai Penelitian Sayuran.

Gupta, S., Kaushal, R. \& Sood, G. (2018). Impact of plant growth-promoting rhizobacteria on vegetable crop production. International Journal of Vegetable Science, 24(3): 389300 .

Hardaningsih, S. (2011). Phytophthora sp. penyebab penyakit rebah semai pada kacang hijau dan pengendaliannya. Seminar Dan Pertemuan Tahunan XXI PEI, PFI Komda Sulawesi Selatan Dan Dinas Perkebunan Pemerintah Provinsi Sulawesi Selatan, pp. 84-91.

Indonesian Commercial Newsletter. (2013). Development of Horticulture Sector in Indonesia. Jakarta: P.T. Data Consult, Inc. Gale, Cengage Learning. 
Jayawardanah, H. A. R. K., Weerahewa, D. \& Saparamadu, M. D. J. S. (2015). Enhanced resistance to anthracnose disease in chilli pepper (Capsicum annuum L.) by amendment of the nutrient solution with silicon. Journal of Horticultural Science and Biotechnology, 90(5): 557-562.

Johnson, G., Weinberger, K. \& Wu, M. E. (2008). The Vegetable Industry in Tropical Asia: An Overview of Production and Trade with a Focus on Thailand, Indonesia, the Philippines, Vietnam, and India. Taiwan: The World Vegetable Center.

Kazuyoshi F., Saki N., Tsuyoshi I. \& Chikara M. (2017). Construction of a system for the strawberry nursery production towards elimination of latent infection of anthracnose fungi by a combination of PCR and microtube hybridization. Plant Pathology of Journal, 33(1): 80-86.

Korlina, E., Krismawati, A., Rachmawati, D. \& Nurvia, E. A. (2013). Penerapan Biopestisida dan Kompos di Musim Penghujan. Prosiding Seminar Nasional 3 in One: Peran Nyata Hortikultura, Agronomi, Pemuliaan Tanaman Dalam Ketahanan Pangan. Malang 21 Agustus 2013, pp. 53-57.

Korlina, Eli, Latifah, E. \& Andri, K. B. (2017). Improving off-season production through grafted tomato technology in East Java Indonesia. Journal of Applied Horticulture, 19(1): 63-66.

Latha, S. \& Hunumanthraya, L. (2018). Integrated management of insect and mite pests of chilli under hill zone of Karnataka. Journal of Entomology and Zoology Studies, 6(2): 2770-2773.

Luther, G. C., Mariyono, J., Purnagunawan, R. M., Satriatna, B. \& Siyaranamual, M. (2018). Impacts of farmer field schools on productivity of vegetable farming in Indonesia. Natural Resources Forum, 42(2): 71-82. https://doi.org/10.1111/14778947.12144
Maramis, A. Y. (2018). Dampak impor cabai dari Tiongkok terhadap perekonomian Indonesia tahun 2010-2015. Jurnal Online Mahasiswa Fisip, 5(1): 1-15.

Mariyono, J., Kuntariningsih, A., Suswati, E. \& Kompas, T. (2018). Quantity and monetary value of agrochemical pollution from intensive farming in Indonesia. Management of Environmental Quality: An International Journal, 29(4): 759-779.

Mariyono, J., Luther, G. C., Bhattarai, M., Ferizal, M., Jaya, R. \& Fitriana, N. (2013). Farmer field schools on chilli peppers in Aceh, Indonesia: activities and impacts. Agroecology and Sustainable Food Systems, 37(9): 1063-1077.

Mariyono, J. (2008). Farmers' economic tolerance toward pest infestations: Impact of Integrated Pest Management training in Indonesia. Quarterly Journal of International Agriculture, 47(1): 61-73.

Mariyono, J. (2009). Technological bias in Indonesian rice production: why does agrochemical use increase over time? Quarterly Journal of International Agriculture, 48(1): 47-65.

Mariyono, J. (2015). Green revolution- and wetland-linked technological change of rice agriculture in Indonesia. Management of Environmental Quality: An International Journal, 26(5): 683-700. https://doi. org/10.1108/MEQ-07-2014-0104

Mariyono, J. (2017). Moving to commercial production: A case of intensive chilli farming in Indonesia. Development in Practice, 27(8): 1103-1113.

Mariyono, J. (2018a). Empowering rural livelihoods through farmers' field school on vegetable production in Aceh ProvinceIndonesia. Journal of Rural Development, 37(1): 129-145.

Mariyono, J. (2018b). Profitability and determinants of smallholder commercial vegetable production. International Journal of Vegetable Science, 24(3): 274-288. 
Mariyono, J. (2019a). Micro-credit as catalyst for improving rural livelihoods through agribusiness sector in Indonesia. Journal of Entrepreneurship in Emerging Economies, 11(1): 98-121.

Mariyono, J. (2019b). Microcredit and technology adoption: Sustained pathways to improve farmers' prosperity in Indonesia. Agricultural Finance Review, 79(1): 85106.

Mariyono, J. (2019c). Stepping up to market participation of smallholder agriculture in rural areas of Indonesia. Agricultural Finance Review, 79(2): 255-270.

Mariyono, J., Kuntariningsih, A. \& Kompas, T. (2018). Pesticide use in Indonesian vegetable farming and its determinants. Management of Environmental Quality: An International Journal, 29(2): 305-323.

Mathivanan, N., Prabavathy, V. R. \& Vijayanandraj, V. R. (2005). Application of talc formulations of Pseudomonas fluorescens Migula and Trichoderma viride Pers. ex S.F. Gray decrease the sheath blight disease and enhance the plant growth and yield in rice. Journal of Phytopathology, 153(11 $\square 12)$ : 697-701.

Ministry of Agriculture. (2020). Last Five Years Data. Jakarta: Ministry of Agriculture. https://www.pertanian.go.id/ home $/$ ?show=page \&act=view\&id=61.

Moosa, A., Sahi, S. T., Haq, I-, U.-, Farzand, A., Khan, S. A. \& Javaid, K. (2017). Antagonistic potential of trichoderma isolates and manures against fusarium wilt of tomato. International Journal of Vegetable Science, 23(3): 207-218.

Morales-Corts, M. R., Pérez-Sánchez, R. \& Gómez-Sánchez, M. Á. (2018). Efficiency of garden waste compost teas on tomato growth and its suppressiveness against soilborne pathogens. Scientia Agricola, 75(5): 400-409.

Murali, M., Amruthesh, K. N., Sudisha, J., Niranjana, S. R. \& Shetty, H. S. (2012).
Screening for plant growth promoting fungi and their ability for growth promotion and induction of resistance in pearl millet against downy mildew disease. Journal of Phytopathology, 4(5): 30-36.

Negoro, A. A. \& Mariyono, J. (2014). Peran sistem informasi dan teknologi luar musim dalam bisnis berbasis komoditas sayuran. Prosiding Seminar Nasional PERHORTI 2014. Malang: PERHORTI.

Orlikowski, L. \& Wolski, T. (2000). The use of composts and their extracts in the biological protection of plants against disease. Ochrona Roslin, 44(2): 34-35.

Paramanandham, P., Rajkumari, J., Pattnaik, S. \& Busi, S. (2017). Biocontrol potential against Fusarium oxysporum f. $\mathrm{sp}$. lycopersici and Alternaria solani and tomato plant growth due to plant growthpromoting rhizobacteria. International Journal of Vegetable Science, 23(4): 294303.

Pretty, J., Toulmin, C. \& Williams, S. (2011). Sustainable intensification in African agriculture. International Journal of Agricultural Sustainability, 9(1): 5-25.

Quarles, W. (2001). Composts tea for organic farming and gardening. IPM Practitioner, 23: $1-9$.

Russo, V. M. (2003). Yields of bell pepper, sweet corn, and peanut in rotations. HortScience, 38(7): 1341-1343. https://doi.org/10.21273/ HORTSCI.38.7.1341

Russo, V. M. (2006). Biological amendment, fertilizer rate, and irrigation frequency for organic bell pepper transplant production. HortScience, 41(6): 1402-1407.

Russo, V. M. \& Perkins-Veazie, P. (2010). Yield and nutrient content of bell pepper pods from plants developed from seedlings inoculated, or not, with microorganisms. HortScience, 45(3): 352-358. https://doi. org/10.21273/HORTSCI.45.3.352

Russo, V. M. \& Taylor, M. (2010). Frequency of manure application in organic versus 
annual application of synthetic fertilizer in conventional vegetable production. HortScience, 45(11): 1673-1680.

Setiawati, W., Udiarto, B. K. \& Muharam, A. (2005). Pengenalan dan Pengendalian Hama-hama Penting pada Tanaman Cabai Merah. Bandung: Balai Penelitian Sayuran.

Siddiqui, Y., Islam, T. M., Yuvarani, N. \& Sariah, M. (2011). The conjunctive use of compost tea and inorganic fertiliser on the growth, yield and terpenoid content of Centella asiatica (L.) urban. Scientia Horticulturae, 130(1): 289-295.

Sinaga, M. S. (2003). Dasar-dasar Penyakit Tumbuhan. Jakarta: Penebar Swadaya.

Tamang, A., Das, I., Batabyal, K., Sarkar, D., Murmu, S., Mandal, B. \& Bhattacharyya, R. (2017). Assessment of nutrient management technologies for broccoli to improve productivity and quality and soil resources in the subtropics. International Journal of Vegetable Science, 23(2): 102-124. https:// doi.org/10.1080/19315260.2016.1216912

Taufik, M., Hidayat, S. H., Suastika, G., Sumaraw, S. M. \& Sujiprihati, S. (2005). Kajian plant growth promoting rhizobacteria sebagai agens proteksi cucumber mosaic virus dan chilli veinal mottle virus pada cabai. Hayati, 12(4): 139-144.

Thakuria, D., Talukdar, N. C., Goswami, C., Hazarika, S. \& Boro, R. C. (2004). Characterization and screening of bacteria from rhizosphere of rice grown in acidic soils of Assam. Current Science, 86(2): 978-985.

Tian, X. \& Zheng, Y. (2013). Compost teas and reused nutrient solution suppress plant pathogens in vitro. Hortscience, 48(4): 510 512.

Tiwari, S. P., Nema, S. \& Khare, M. N. (2013). Whitefly - a strong transmitter of plant viruses. International Journal of Phytopathology, 2(2): 102-120.

Yoshihiro, T., Matsuda, Y., Teruo, N., Koji, K., Okada, K., Shinya, M., Manabu, S., Shinichi, K. \& Toyoda, H. (2016). An electrostatic nursery shelter for raising pest and pathogen free tomato seedlings in an open-window greenhouse environment. Journal of Agricultural Science, 8(4): 1325. 